\title{
PENGARUH MEDIA KATALOG TERHADAP KEAKTIFAN DAN HASIL BELAJAR MATEMATIKA EKONOMI MAHASISWA PROGRAM STUDI PENDIDIKAN AKUNTANSI FKIP UNIVERSITAS PGRI PALEMBANG
}

\author{
Oleh: Merlyn Widalismana ${ }^{1}$, Erma Yulaini, Sandy Wiwid, Fitria Anggrainy \\ (UNIVERSITAS PGRI PALEMBANG) \\ 1)merlynwidalismana12@gmail.com
}

\begin{abstract}
Abstrak
Tujuan penelitian untuk mengetahui pengaruh media katalog terhadap keaktifan belajar dan hasil belajar mahasiswa pada materi Matematika Ekonomi. Populasi seluruhnya 52 mahasiswa dari 2 kelas. Metode penelitian dalam penelitian ini menggunakan metode eksperimen dengan one group pretest-posttes design. Analisis tes keaktifan (pretest dan posttest) menggunakan paired sample t test mendapatkan hasil nilai probabilitas atau signifikansi (2-tailed) sebesar 0,000. Nilai t hitung sebesar 6,350, t tabel untuk of 51 adalah 1,6753, maka nilai thitung lebih besar terhadap nilai $t$ tabel $(9,465>1,7653)$. Sehingga dapat dinyatakan bahwa penggunaan media pembelajaran katalog dapat berpengaruh terhadap peningkatan keaktifan belajar mahasiswa dengan sangat signifikan (0,000). Sehingga ditarik kesimpulan bahwa hipotesis satu diterima. Dan ada pengaruh yang signifikan penggunaan media pembelajaran katalog terhadap keaktifan mahasiswa berdasarkan hasil perhitungan menggunakan perhitungan yang sama yaitu paired sample $t$ test dengan menganalisis nilai hasil pretest dan posttest didapatkan hasil nilai probabilitas atau signifikansi (2-tailed) sebesar 0,000. Nilai thitung sebesar 9,465, t tabel untuk df 51 adalah 1,6753, maka nilai thitung lebih besar daripada nilai $t$ tabel $(9,465>1,6753)$. Sehingga dapat dinyatakan bahwa penggunaan media pembelajaran katalog dapat berpengaruh terhadap peningkatan hasil belajar mahasiswa dengan signifikan (0,000), sehingga disimpulkan hipotesis dua diterima.
\end{abstract}

Kata Kunci: Media katalog, Keaktifan, dan Hasil Belajar.

\section{THE INFLUENCE OF CATALOG MEDIA TO LIVELINESS AND LEARNING OUTCOME MATHEMATICAL ECONOMIC COURSES OF STUDENT COLLEGE ON ACCOUTING EDUCATION FKIP PGRI UNIVERSITY PALEMBANG}

\begin{abstract}
Abstrack
The objective of this research are to investigate the influence of the catalog media in the learning activeness and student learning result in the Mathematics of Economics. The population of this research are 52 students from 2 classes. This research used experimental research method with one group pretest-posttes design. The activeness data were analyzed by using paired sample t test and the result of probability or significance (2-tailed) are 0.000. $t$ hitung score are 6.350
\end{abstract}


and t table for df 51 are 1.6753, it means that the score of thitung greater than $t$ table $(9,465>1.7653)$. So it can be conclude that the use of catalog media has the positive effect on the improvement of student activeness with a very significant (0.000), it means that hypothesis one is accepted. And there is a significant effect of the use of catalog media in the activeness of students based on the calculation results using the same calculation of paired sample $t$ test by analyzing score of pretest and posttest results obtained the results of probability or significance (2tailed) are 0.000. the score of thitung are 9.465 and t table for $d f 51$ are 1.6753, so it means that the score of $t$ hitung greater than $t$ table $(9,465>1,6753)$. It conclude that the used of catalog media has a positive effect on the improvement of students learning result with significance (0.000). It means that hypothesis one is accepted.

Keywords: Catalog Media, Activeness, Learning Result.

\section{PENDAHULUAN}

Pendidikan dan pengajaran menjadi salah satu dari Tri Darma perguruan tinggi yang tidak bisa dimanipulasi pelaksanaannya hal ini sesuai dengan Undang-undang no. 12 tahun 2012 tentang Pendidikan Tinggi. Proses ini adalah penentu suatu ilmu tersampaikan, tersematkan, dan teraplikasikan oleh seorang mahasiswa pada akhirnya. Kenyataannya, proses pembelajaran yang sudah lazim dijalankan dalam suatu institusi perguruan tinggi disetiap perjalanannya terus memiliki tantangan dan hambatan. Proses ini tidak bisa semata-mata berjalan sama disetiap tahun pembelajaran. Perbedaan dari situasi, kurikulum, target tercapainya kompetensi, perkembangan teknologi sampai pada daya serap peserta didik sangat mempengaruhi kemaksimalan hasil dari proses pengajaran. Sehingga menjadi suatu tantangan tersendiri bagi seorang pengajar khususnya dosen untuk bisa berinovasi dalam proses belajar dan pengajaran.

Inovasi tersebut dapat dibuat dalam berbagai bentuk, dengan tujuan memaksimalkan proses pengajaran yang akan menghasilkan hasil yang maksimal, yaitu mahasiswa berwawasan yang sesuai dengan bidang keilmuan yang didalami. Salah satu inovasi yang dapat dilakukan untuk menunjang proses pembelajaran dan berperan dalam proses tersebut adalah media pembelajaran.

Sebenarnya, 
pembahasan media pembelajaran merupakan sesuatu yang klasik, hal ini dikarenakan media pembelajaran sudah menjadi hal biasa yang harus difikirkan oleh semua pengajar mulai dari tingkat sekolah dasar dan lainnya. Namun menurut Erowati. T dkk (2015:295), hal ini juga yang menjadi tantangan untuk terus bisa mengambangakan dan menemukan berbagai media baru, untuk menghindari kebosanan dalam proses pembelajaran yang akan sangat mengganggu.

Melalui media pembelajaran diharapkan penyampaian yang diberikan media pembelajaran mengandung informasi yang berkesinambungan dengan kehidupan nyata menurut Adegbija, dkk (2012:227). Hal ini sesuai dengan tindak lanjut kurikulum yang mengacu pada pengaplikasian dengan kehidupan yang sebenarbenarnya. Menurut Anitah (2009:6) seiring dengan pentingnya media dalam kegiatan pembelajaran, guru dituntut untuk lebih kreatif dan inovatif dalam merancang kegiatan belajar untuk menciptakan lingkungan belajar yang kondusif khususnya pada mata pelajaran matematika ekonomi. Media pembelajaran yang sesuai dengan karasteristik materi sehingga mampu merangsang mahasiswa untuk lebih aktif dalam merespon materi yang disampaikan. Media pembejalaran adalah segala sesuatu yang dapat menyalurkan pesan dari pengirim kepada penerima atau menyampaikan materi dari dosen kepada mahasiswa sehingga dapat merangsang pemikiran mahasiswa. Dengan demikian dalam belajar dosen mampu berkreasi dan berinovasi dalam menciptakan media pembelajaran yang bisa disajikan dalam proses belajar mengajar. Sedangkan menurut Hamdani (2011:244) media pembelajaran merupakan segala sesuatu yang dapat menyalurkan pesan, merangsang pikiran dan kemauan mahasiswa sehingga mendorong terciptanya proses belajar pada diri sendiri.

Selanjutnya berdasarkan pada penjabaran tersebut digabungkan dengan salah satu mata kuliah dalam program studi pendidikan akuntansi yaitu matematika ekonomi yang merupakan salah satu matakuliah 
yang dianggap sulit oleh mahasiswa (berdasarkan studi pendahuluan yang dilakukan peneliti dengan mengkaji nilai, proses, dan tanya jawab mahasiswa). Selain pada ketiga kajian dalam studi pendahuluan pemilihan matematika ekonomi sebagai salah satu variabel dikarenakan matakuliah ini menjadi salah satu matakuliah prasarat yang diharuskan lulus untuk bisa mengambil matakuliah selanjutnya. Maka, penelitian ini mencoba mencari media yang mampu menjadi solusi untuk bisa memecahkan masalah sulitnya menguasai materi dalam matakuliah matematika ekonomi tersebut.

Media yang coba dikembangkan ini diharapkan memiliki kelebihan mengakomodir berbagai katakunci informasi yang memudahkan mahasiswa saat mempelajari setiap materi dan mampu memberikan gambaran atau keterkaitan tentang pengaplikasian didunia nyata berdasarkan informasi yang ada disekitarnya dan dapat diperharui berdasarkan setiap peristiwa atau informasi media cetak Anita (2014:8). Pemunculan informasi yang ada didunia nyata ini sebagai dorongan mahasiswa memahami dengan dasar kejadian nyata (pengkaitan materi dengan kegunaan sehari-hari), hal ini dimaksudkan memberikan pengalaman yang mendorong untuk lebih mudah menangkap dari apa yang dipelajari. Sehingga, menurut Sukiyasa. K, dkk (2013:135) bentuk media tersebut dibuat seperti sebuah katalog yang memberikan informasi berupa rumus yang tersusun juga informasi yang terkait terhadap penggunaan yang ada dimasyarakat juga sedekat mungkin dan dapat diperbaharui sesuai dengan berkembangnya informasi yang ada. Dengan demikian peneliti menggangkat judul penelitian "Pengaruh Media Katalog Terhadap Keaktifan Belajar dan Hasil Belajar Matematika Ekonomi Mahasiswa Program Studi Pendidikan Akuntansi FKIP Universitas PGRI Palembang”.

\section{METODE PENELITIAN}

Jenis penelitian ini adalah jenis penelitian one group pretestposttes design. Dilakukan pengukuran variabel tergantung dari 
satu kelompok subjek (pretest), kemudian subjek diberikan perlakuan dalam jangka waktu tertentu (eksposure) mahasiswa. Selanjutnya melakukan pengukuran posttest hasil pengukuran awal dibandingkan dengan hasil pengukuran akhir (Suryabrata, 2000:55). Perlakukan yang dilakukan adalah memberikan pembelajaran dengan menggunakan media katalog dan disaat sama dilakukan penilaian terhadap keaktifan dari setiap mahasiswa.

\section{TEKNIK}

PENGUMPULAN

\section{DATA}

Proses pengumpulan data yang pertama adalah dengan observasi. Menurut Sugiono (2013:203) observasi adalah suatu proses yang kompleks, yang tersusun dari proses pengamatan mengenai tingkahlaku individu atau kelompok. Menggunakan metode observasi cara yang paling efektif adalah melengkapinya dengan format atau blangko pengamatan sebagai instrumen. Penelitian ini membutuhkan dua data yang tepat yaitu nilai keaktifan dan dan hasil belajar mahasiswa. Kedua nilai tersebut didapatkan dengan menggunakan tes (pretest dan posttest) berdasarkan instrumen yang dipersiapkan.

\section{TEKNIK ANALISIS DATA}

Teknik analisis data digunakan untuk mendapatkan gambaran yang lebih jelas dari data hasil penelitian dan untuk mendapatkan kesimpulan. Dalam menganalisis data menggunakan paired sample $t$ test yaitu uji yang menggunakan dua data sampel yang berpasangan yaitu berdasarkan nilai pretest dan posttest sehingga dari tes ini akan diketahui pengaruh penggunaan media pembelajaran katalog pada kedua variabel terikat yaitu keaktifan dan hasil belajar namun sebelum melakukan uji paired sample t test akan dilakukan uji prasyarat terlebih dahulu yaitu uji normalitas dan uji homogenitas. Untuk perhitungan analisis ini akan dibantu dengan penggunaan SPSS. 17.0 Equinox.

\section{HASIL DAN PEMBAHASAN}

Penelitian ini dilakukan di Program Studi Pendidikan Akuntansi FKIP Universitas Palembang. 
Sampel dalam penelitian ini adalah mahasiswa kelas 3A dan 3B, yaitu: kelas 3A dan kelas 3B sebagai dengan jumlah 52 mahasiswa dan penelitian ini dilakukan sebanyak 3 kali pertemuan.

\section{HASIL PENELITIAN}

\section{a. Deskripsi Data Hasil Penelitian}

Rata-rata skor hasil belajar untuk 3A adalah 59,79 dengan standar deviasi 3,96. Dan untuk ratarata skor hasil belajar pada kelas $3 \mathrm{~B}$ adalah 3,96 dengan standar deviasi 7,62. Agar penyajian data menjadi lebih jelas, penulis menampilkan tabel distribusi frekuensi hasil pretest dari masing-masing variabel ke dalam tabel distribusi frekuensi berikut. Setelah dilakukan perhitungan dengan rumus Struges untuk menentukan banyaknya kelas interval dan panjang interval.

1. Hasil pretest variabel hasil belajar kelas $3 \mathrm{~A}$

Hasil pretest variabel hasil belajar kelas kontrol untuk lebih jelasnya ditampilkan pada tabel berikut:

Tabel 1 Distribusi Skor pretest Hasil Belajar Kelas 3A

\begin{tabular}{|c|c|c|c|}
\hline No & Kelas interval & Frekuensi & Persen (\%) \\
\hline 1 & $59-62$ & 11 & $40,74 \%$ \\
\hline 2 & $63-66$ & 6 & $22,22 \%$ \\
\hline 3 & $67-70$ & 8 & $33,33 \%$ \\
\hline 4 & $71-74$ & 1 & $3,7 \%$ \\
\hline 5 & $75-79$ & 1 & $3,7 \%$ \\
\hline \multicolumn{2}{|c|}{ Jumlah } & 23 & 100 \\
\hline
\end{tabular}

Sumber : Data Primer, 2017.

Berdasarkan tabel tersebut tertinggi yaitu 75-79 yang berjumlah dapat disimpulkan bahwa kelas 1 mahasiswa dengan persentase interval terendah untuk hasil pretest 3,7\%. Frekuensi terbanyak dari hasil variabel hasil belajar pada kelas eksperimen adalah 59-62 dengan pretest hasil belajar adalah $67-70$ dengan jumlah mahasiswa 9 dan frekuensi berjumlah 11 mahasiswa besar persentase $33,33 \%$ dari dan besar persentase 40,74\%. keseluruhan jumlah sampel. Untuk Sedangkan untuk kelas interval 
lebih jelas, maka ditampilkan pada diagram batang berikut ini.

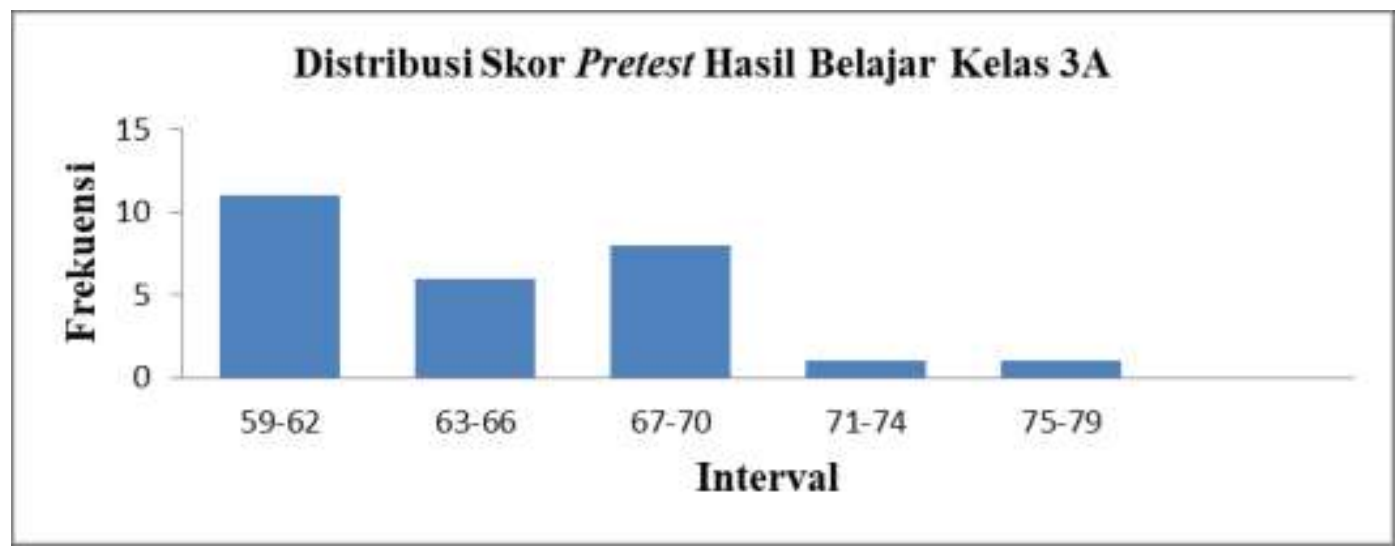

Gambar 1. Grafik distribusi skor pretest hasil belajar kelas 3A

2. Hasil pretest variabel hasil

belajar kelas 3B

Hasil pretest variabel hasil

belajar kelas 3B untuk lebih jelasnya

ditampilkan pada tabel berikut:

Tabel 2 Distribusi Skor pretest Hasil Belajar Kelas 3B

\begin{tabular}{|c|c|c|c|}
\hline No & Kelas Interval & Frekuensi & Persen (\%) \\
\hline 1 & $51-56$ & 4 & $14,81 \%$ \\
\hline 2 & $57-62$ & 8 & $29,62 \%$ \\
\hline 3 & $63-68$ & 9 & $33,33 \%$ \\
\hline 4 & $69-74$ & 1 & $3,70 \%$ \\
\hline 5 & $75-80$ & 2 & $7,40 \%$ \\
\hline 6 & $81-86$ & 1 & $3,70 \%$ \\
\hline \multicolumn{2}{|r|}{ Jumlah } & 25 & 100 \\
\hline
\end{tabular}

Sumber : Data Primer, 2017.

Berdasarkan tabel tersebut dapat disimpulkan bahwa kelas interval terendah untuk hasil pretest variabel hasil belajar pada kelas $3 \mathrm{~B}$ adalah 51-56 dengan frekuensi berjumlah 4 mahasiswa dan besar persentase $14,81 \%$. Sedangkan untuk kelas interval tertinggi yaitu $81-86$ yang berjumlah 1 mahasiswa dengan persentase $\quad 3,70 \%$. Frekuensi terbanyak dari hasil pre test hasil belajar adalah 63-68 dengan jumlah mahasiswa 9 dan besar persentase $33,33 \%$ dari keseluruhan jumlah 
sampel. Untuk lebih jelas, maka berikut ini.

ditampilkan pada diagram batang

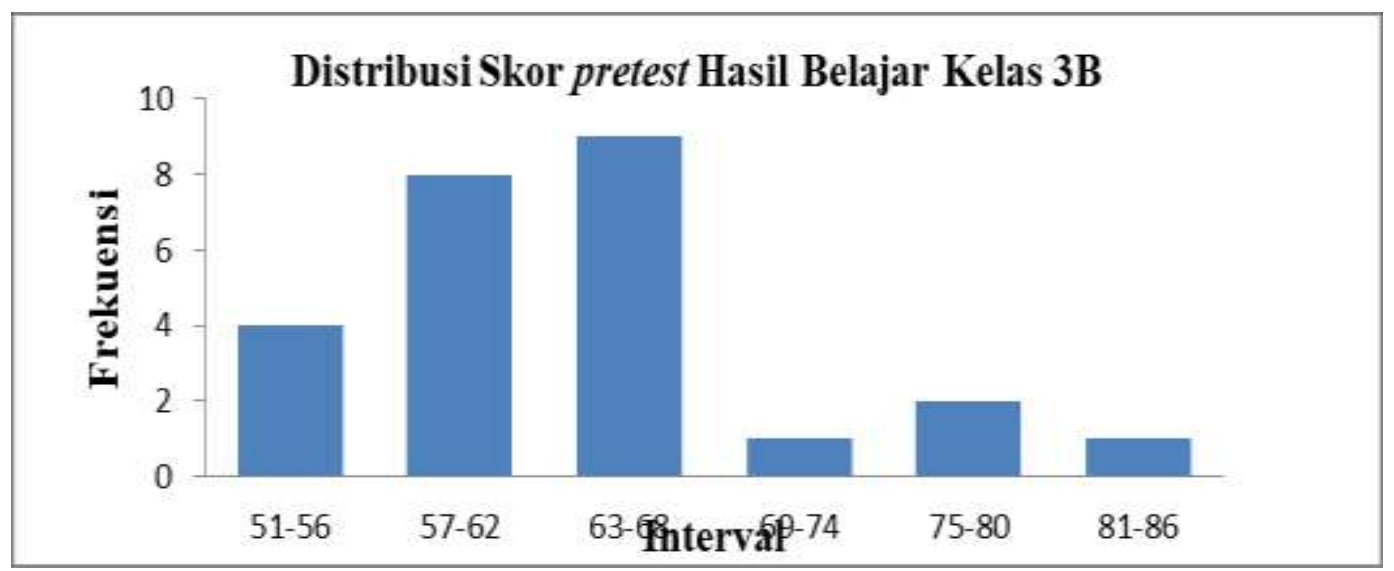

Gambar 2. Grafik distribusi skor pretest hasil belajar kelas 3B

Rata-rata skor hasil belajar berikut. Setelah dilakukan untuk kelas $3 \mathrm{~A}$ adalah 80,79 dengan perhitungan dengan rumus Struges standar deviasi 6,19. Dan untuk ratauntuk menentukan banyaknya kelas rata skor hasil belajar pada kelas $3 \mathrm{~A}$ adalah 62,65 dengan standar deviasi 9,12 . Agar penyajian data menjadi lebih jelas, penulis menampilkan tabel distribusi frekuensi hasil interval dan panjang interval.

a. Deskripsi posttest Hasil Belajar Kelas 3A

Hasil posttest variabel hasil posttest dari masing-masing variabel belajar kelas 3A untuk lebih jelasnya ke dalam tabel distribusi frekuensi ditampilkan pada tabel berikut:

Tabel 3. Distribusi Skor posttest Hasil Belajar Kelas 3A

\begin{tabular}{|c|c|c|c|}
\hline No & Kelas Interval & Frekuensi & Persen (\%) \\
\hline 1 & $76-80$ & 5 & $18,52 \%$ \\
\hline 2 & $81-85$ & 3 & $11,11 \%$ \\
\hline 3 & $86-90$ & 13 & $48,14 \%$ \\
\hline 4 & $91-95$ & 3 & $11,11 \%$ \\
\hline 5 & $96-100$ & 3 & $11,11 \%$ \\
\hline \multicolumn{2}{|c|}{ Jumlah } & 27 & 100 \\
\hline
\end{tabular}

Sumber : Data Primer, 2017.

Berdasarkan tabel tersebut interval terendah untuk hasil posttest dapat disimpulkan bahwa kelas variabel hasil belajar pada kelas 3A 
adalah 76-80 dengan frekuensi berjumlah 5 mahasiswa dan besar persentase $18,52 \%$. Sedangkan untuk kelas interval tertinggi yaitu 96-100 yang berjumlah 3 mahasiswa dengan persentase $11,11 \%$. Frekuensi terbanyak dari hasil protest hasil belajar adalah 86-90 dengan jumlah mahasiswa 13 dan besar persentase $48,14 \%$ dari keseluruhan jumlah sampel. Untuk lebih jelas, maka ditampilkan pada diagram batang berikut ini.

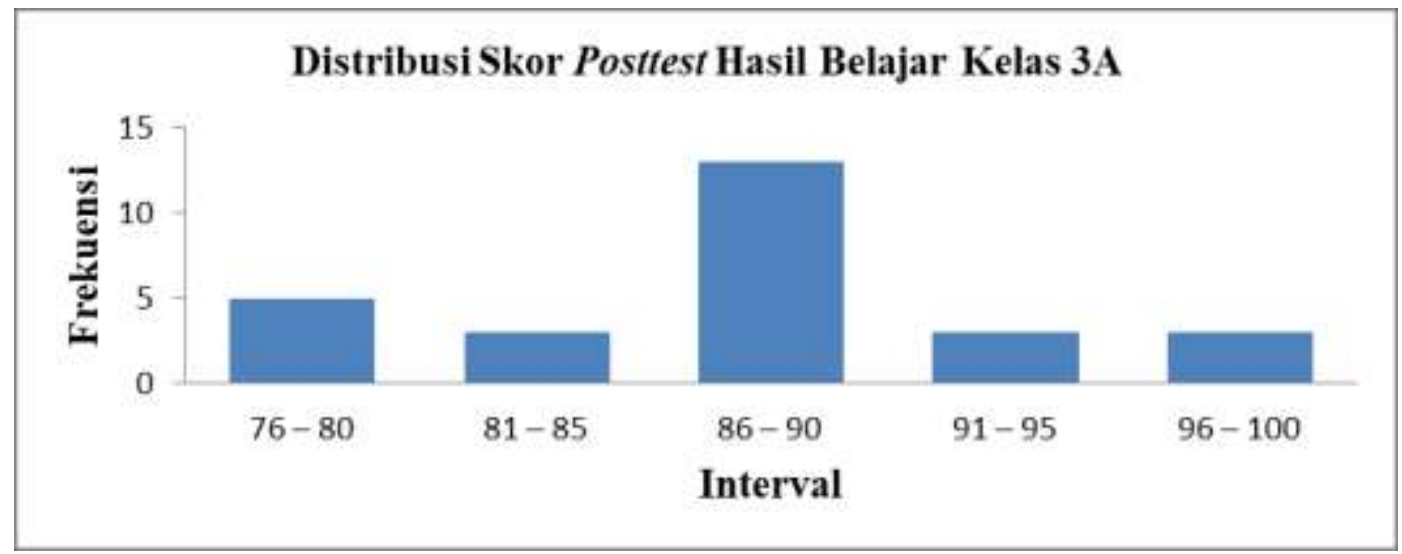

Gambar 3. Grafik distribusi skor posttest hasil belajar kelas 3A

b. Deskripsi posttest Hasil

Hasil posttest hasil belajar Belajar Kelas 3B kelas kontrol untuk lebih jelasnya ditampilkan pada tabel berikut.

Tabel 4. Distribusi Skor posttest Hasil Belajar Kelas 3B

\begin{tabular}{|c|c|c|c|}
\hline No & Kelas Interval & Frekuensi & Persen (\%) \\
\hline 1 & $55-61$ & 4 & $16 \%$ \\
\hline 2 & $62-68$ & 5 & $20 \%$ \\
\hline 3 & $69-75$ & 9 & $36 \%$ \\
\hline 4 & $76-82$ & 3 & $12 \%$ \\
\hline 5 & $83-89$ & 3 & $12 \%$ \\
\hline 6 & $90-96$ & 1 & $4 \%$ \\
\hline \multicolumn{2}{|r|}{ Jumlah } & 25 & 100 \\
\hline
\end{tabular}

Sumber : Data Primer, 2014.

Berdasarkan tabel tersebut berjumlah 4 mahasiswa dan besar dapat disimpulkan bahwa kelas persentase $16 \%$. Sedangkan untuk interval terendah untuk hasil posttest kelas interval tertinggi yaitu 90-96 variabel hasil belajar pada kelas 3B yang berjumlah 1 mahasiswa dengan adalah 55-61 dengan frekuensi persentase $4 \%$. Frekuensi terbanyak 
dari hasil posttest hasil belajar adalah 69-75 dengan jumlah mahasiswa 9 dan besar persentase $36 \%$ dari keseluruhan jumlah sampel. Untuk lebih jelas, maka ditampilkan pada diagram batang berikut ini.

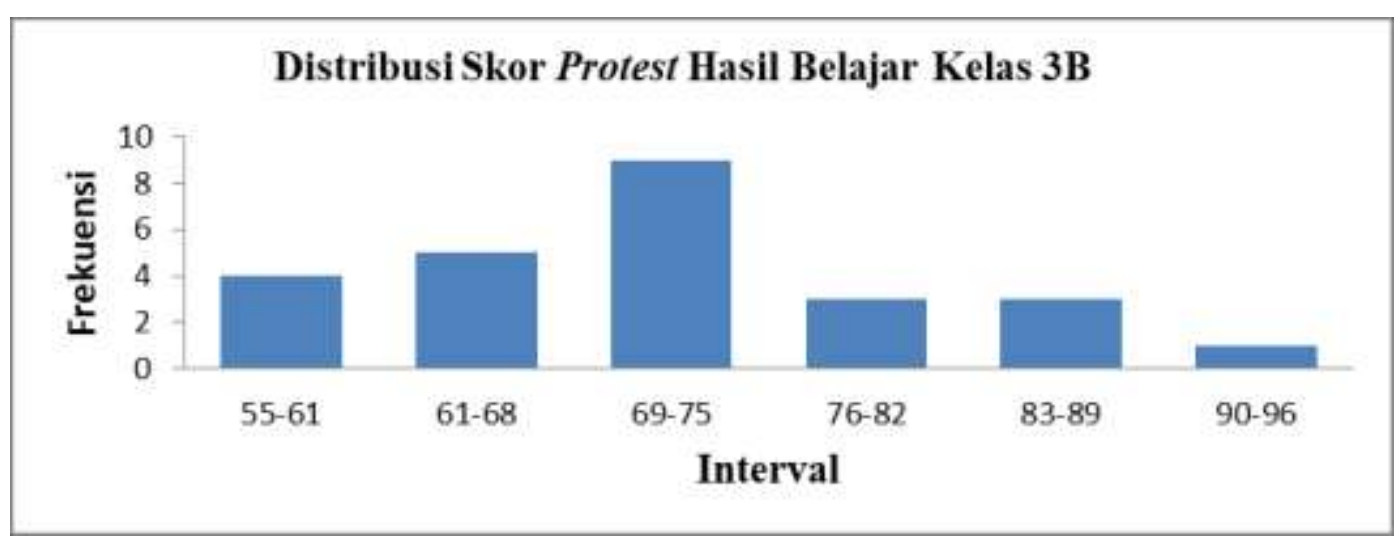

Gambar 4. Grafik distribusi skor posttest hasil belajar kelas 3B

\section{Pengujian Persyaratan Penelitian}

a. Uji Normalitas

Bedasarkan data yang

didapat, kemudian dilakukan analisis uji prasyarat yaitu uji normalitas. Hasil dari uji normalitas yang dilakukan dengan bantuan SPPS ini adalah sebagi berikut:

Tabel 5. Tests of Normality

\begin{tabular}{|l|r|r|r|r|r|r|}
\hline \multirow{2}{*}{} & \multicolumn{3}{|c|}{ Kolmogorov-Smirnov $^{\mathrm{a}}$} & \multicolumn{3}{|c|}{ Shapiro-Wilk } \\
\cline { 2 - 7 } & Statistic & \multicolumn{1}{c|}{$\mathrm{df}$} & \multicolumn{1}{c|}{ Sig. } & Statistic & \multicolumn{1}{c|}{$\mathrm{df}$} & \multicolumn{1}{c|}{ Sig. } \\
\hline Normalitas & .122 & 52 & .052 & .971 & 52 & .230 \\
\hline
\end{tabular}

a. Lilliefors Significance Correction

Tabel diatas merupakan print out dari hasil pencarian menggunakan alat bantu perhitungan SPSS, dari data diatas terdapat dua pendapat angka hail uji normalitas yaitu sebesar 0,052 (KolmogorofSmirnof) dan 0,230 (Shapiro-Wilk). Angka tersebut lebih besar dari $\alpha=$ $0,05(0,052>0,05)$ atau $(0,230>0,05)$, maka dapat dinyatakan data berdistribusi normal.

a. Uji Homogenitas

Penggunaan uji prasyarat pada analisis paired sampel $t$ test tidak menjadi prasyarat diutamakan namun peneliti tetap melakukan analisis untuk uji homogeny dan mendapatkan hasil sebagai berikut: 
Tabel 6. Levene's Test of Equality of Error Variances/Uji Homogenitas

Pretest
\begin{tabular}{|c|c|c|c|}
\hline Levene Statistic & df1 & df2 & Sig. \\
\hline .599 & 12 & 23 & .821 \\
\hline
\end{tabular}

Data yang didapat dari hasil print out analisis uji homogen atau tabel diatas adalah angka signifikan sebesar 0,821. angka ini lebih besar dari pada nilai $\alpha=0,05$ $(0,821>0,05), \quad$ maka dapat disimpulkan bahwa data sampel tersebut sama atau homogen. Kedua uji prasyarat yang dilakukan memberikan angka signifikansi yang menunjukkan data sample berdistribusi normal dan homogen. Kedua prasyarat ini memungkinkan peneliti melanjutkan perhitungan analisis paired sampel t test.

\section{Hasil Analisis Data}

Analisis data pada penelitian ini menggunakan paired sampel $t$ test. Analisis ini dilakukan satu persatu yaitu menggunakan data pretest dan posttest masing-masing variabel terikat, yaitu keaktifan $\left(\mathrm{Y}_{1}\right)$ dan hasil belajar $\left(\mathrm{Y}_{2}\right)$. Berdasarkan analisis yang sudah dilakukan didapatkan hasil sebagai berikut:

a. Variabel Keaktifan

Tabel 7. Paired Samples Test Keaktifan

\begin{tabular}{|c|c|c|c|c|c|c|c|c|}
\hline & \multicolumn{5}{|c|}{ Paired Differences } & \multirow[b]{3}{*}{$\mathrm{t}$} & \multirow[b]{3}{*}{ df } & \multirow{3}{*}{$\begin{array}{l}\text { Sig. (2- } \\
\text { tailed) }\end{array}$} \\
\hline & \multirow[b]{2}{*}{ Mean } & \multirow{2}{*}{$\begin{array}{c}\text { Std. } \\
\text { Deviation }\end{array}$} & \multirow{2}{*}{$\begin{array}{l}\text { Std. } \\
\text { Error } \\
\text { Mean }\end{array}$} & \multicolumn{2}{|c|}{$\begin{array}{l}95 \% \text { Confidence } \\
\text { Interval of the } \\
\text { Difference }\end{array}$} & & & \\
\hline & & & & Lower & Upper & & & \\
\hline $\begin{array}{ll}\text { Pair } & \text { posttest } \\
1 & \text { - pretest }\end{array}$ & 1.11923E1 & 12.71102 & 1.76270 & 7.65354 & 14.73108 & 6.350 & 51 & .000 \\
\hline
\end{tabular}

Hasil analisis menggunakan uji paired sample $t$ test untuk keaktifan seperti tabel diatas didapatkan nilai probabilitas atau signifikansi (2-tailed) sebesar 0,000. Nilai ini lebih kecil dari nilai derajat kepercayaan $5 \%$ atau $0,05 \quad(0,000$ $<0,05)$ dan nilai $t$ hitung sebesar 6,350 , t tabel untuk df 51 adalah 1,6753, makan nilai t hitung lebih besar terhadap nilai $\mathrm{t}$ tabel $(9,465>1,7653)$. Sehingga dapat 
dinyatakan bahwa penggunaan media pembelajaran katalog dapat berpengaruh terhadap peningkatan keaktifan mahasiswa.

b. Variabel Hasil Belajar

Tabel 8. Paired Samples Test hasil belajar

\begin{tabular}{|c|c|c|c|c|c|c|c|c|}
\hline & \multicolumn{5}{|c|}{ Paired Differences } & \multirow[b]{3}{*}{$\mathrm{t}$} & \multirow[b]{3}{*}{ df } & \multirow{3}{*}{$\begin{array}{l}\text { Sig. (2- } \\
\text { tailed) }\end{array}$} \\
\hline & \multirow[b]{2}{*}{ Mean } & \multirow{2}{*}{$\begin{array}{c}\text { Std. } \\
\text { Deviation }\end{array}$} & \multirow{2}{*}{$\begin{array}{l}\text { Std. } \\
\text { Error } \\
\text { Mean }\end{array}$} & \multicolumn{2}{|c|}{$\begin{array}{l}95 \% \text { Confidence } \\
\text { Interval of the } \\
\text { Difference }\end{array}$} & & & \\
\hline & & & & Lower & Upper & & & \\
\hline $\begin{array}{ll}\text { Pair } & \text { pretest - } \\
1 & \text { posttest }\end{array}$ & $\begin{array}{r}1.66731 \\
\mathrm{E} 1\end{array}$ & 12.70282 & 1.76156 & 13.13659 & 20.20956 & 9.465 & 51 & .000 \\
\hline
\end{tabular}

Hasil analisis menggunakan uji paired sample $t$ test seperti tabel diatas didapatkan nilai probabilitas atau signifikansi (2-tailed) sebesar 0,000. Nilai ini lebih kecil dari nilai derajat kepercayaan $5 \%$ atau 0,05 $(0,000<0,05)$ dan nilai $t$ hitung sebesar 9,465, t tabel untuk df 51 adalah 1,6753, makan nilai t hitung lebih besar terhadap nilai $\mathrm{t}$ tabel $(9,465>1,7653)$. Sehingga dapat dinyatakan bahwa penggunaan media pembelajaran katalog dapat berpengaruh terhadap peningkatan hasil belajar mahasiswa.

\section{Pembahasan}

Media pada dasarnya dibuat sebagai suatu perantara dari pemberi kepada tujuan, dan media pembelajaran adalah sebuah alat yang digunakan untuk menyampaikan sebuah ilmu agar sampai pada penerima yaitu mahasiswa. Hal ini sejalan dengan apa yang disampaikan oleh Anitah (2009: 6) bahwa setiap media merupakan sarana untuk menuju ke suatu tujuan. Maka, dalam penelitian ini mencoba mengungkap adakah pengaruh media katalog ini dalam pembelajaran matematika ekonomi membantu menyampaikan isi dari berbagai ilmu yang terkandung dalam media katalog ini.

Berdasarkan pada penelitian yang telah dilakukan dan angka yang didapat setelah analisis dilakukan terdapat beberapa dukungan penggunaan media katalog, yaitu yang pertama untuk membuktikan hipotesis satu dan dua, Ada atau 
tidaknya pengaruh yang signifikan penggunaan media pembelajaran katalog terhadap keaktifan mahasiswa pada mata kuliah matematika ekonomi Program Studi Pendidikan Akuntansi FKIP Universitas PGRI Palembang, pembuktian ini terjawab pada hasil dari analisis nilai yang didapat pada tes keaktifan (pretest dan posttest) dan dianalisis menggunakan paired sample $t$ test mendapatkan hasil nilai probabilitas atau signifikansi (2tailed) sebesar 0,000. Nilai ini lebih kecil dari nilai derajat kepercayaan $5 \%$ atau $0,05(0,000<0,05)$ dan nilai $\mathrm{t}$ hitung sebesar 6,350, $\mathrm{t}$ tabel untuk df 51 adalah 1,6753, makan nilai $\mathrm{t}$ hitung lebih besar terhadap nilai $\mathrm{t}$ tabel $(9,465>1,7653) . \quad$ Sehingga dapat dinyatakan bahwa penggunaan media pembelajaran katalog dapat berpengaruh terhadap peningkatan keaktifan belajar mahasiswa dengan sangat signifikan $(0,000)$, Sehingga hipotesis dapat ditarik kesimpulan bahwa hipotesis satu diterima.

Uji tersebut menjawab bahwa penggunaan media katalog mempunyai pengaruh. Maka, dalam penggunaan media pembelajaran untuk matakuliah matematika ekonomi, media pembelajaran ini dapat menjadi salah satu alternatif yang bisa dipilih bagi seorang dosen dalam menyampaikan materi pembelajaran dalam matakuliah matematika ekonomi. Selain pengajar tentu dengan media yang memiliki banyak informasi didalamnya mengenai materi yang didukung, peserta didik dalam hal ini mahasiswa dapat dengan mudah mendapatkan informasi terkait materi yang sedang dipelajari tanpa harus menganalisis apakah informasi yang ada diluaran merupakan materi yang mendukung seperti yang terdapat pada media katalog tersebut.

Jika dikaitkan dengan proses pada saat penelitian tentang pengaruh media pembelajaran katalog ini terhadap keaktifan, nampak terlihat pada berbagai penilaian keaktifan yang ada pada lembar penilaian peserta didik (mahasiswa). Keaktifan ini sesuai dengan setiap item penilaian pada instrumen penilaian keaktifan yaitu:

1. Keseluruhan mahasiswa tertarik untuk membuka, mengamati isi dari media 
katalog, membandingkan antara apa yang disampaikan oleh pengajar dan isi dari media katalog hingga pembelajaran terasa hening dengan perhatian penuh mahasiswa pada apa yang disampaikan dikelas. Perhatian mahasiswa ini dibuktikan dengan mahasiswa dapat mengerjakan tugas-tugas yang ada dalam media katalog dengan cepat dan tepat sesuai dengan petunjuk yang disampaikan pengajar.

2. Mahasiswa mampu mengungkapkan pertanyaan-pertanyaan sesuai materi, mempresentasikan pendapat, menyangga pendapat teman, kemudian juga saling membenarkan kesalahan-kesalahan pendapat yang muncul.

3. Ketertarikan siswa pada penyampaian melalui media katalog merangsang mahasiswa cepat dan tanggap dalam bergerak, yaitu mencatat apa yang disampaikan oleh pengajar, pendapat-pendapat teman sekelas dalam pembelajaran, juga mencatat pendapatnya sebelum mempresentasikan kepada teman lainnya. Selain itu pergerakan diskusi antar teman terasa tanpa ada diselingi dengan perbincangan diluar materi yang sedang dipelajari.

4. Semua proses yang dialami dalam pembelajaran yang didukung oleh penggunaan media pembelajaran katalog selama penelitian ini juga menunjukkan sikap mahasiswa menjadi sistematis, yaitu mahasiswa mengontrol pendapat yang disampaikan tidak keluar dari konteks materi pembelajaran, mahasiswa mengungkapkan pendapat dengan berurutan sesuai pengkelompokan dalam tugas yang ada didalam media tersebut. Sehingga, 
pembelajaran lebih teratur tanpa ada seranganserangan pendapat yang saling menjatuhkan atau keluar dari konteks pembelajaran.

Disimpulkan bahwa media pembelajaran katalog ini berpengaruh terhadap keaktifan mahasiswa dalam proses pembelajaran matematika ekonomi. Kemudian untuk membuktikan media pembelajaran katalog ini membuktikan hipotesis dua, pengaruh yang signifikan penggunaan media pembelajaran katalog terhadap hasil belajar mahasiswa pada mata kuliah matematika ekonomi Program Studi Pendidikan Akuntansi FKIP Universitas PGRI Palembang, dengan menggunakan perhitungan yang sama yaitu paired sample $t$ test dengan menganalisis nilai hasil pretest dan posttest didapatkan hasil nilai probabilitas atau signifikansi (2tailed) sebesar 0,000. Nilai ini lebih kecil dari nilai derajat kepercayaan $5 \%$ atau $0,05(0,000<0,05)$ dan nilai t hitung sebesar 9,465, t tabel untuk df 51 adalah 1,6753, makan nilai $\mathrm{t}$ hitung lebih besar terhadap nilai $\mathrm{t}$ tabel $(9,465>1,6753)$. Sehingga dapat dinyatakan bahwa penggunaan media pembelajaran katalog dapat berpengaruh terhadap peningkatan hasil belajar mahasiswa dengan signifikan $\quad(0,000), \quad$ sehingga disimpulkan hipotesis dua diterima.

Peningkatan hasil belajar ini tidak terlepas dari proses yang dijalani. Media pembelajaran yang tepat yang dapat memberikan pengaruh yang baik dalam proses belajar akan memberikan dampak pada hasil. proses pembelajaran dengan menggunakan media pembelajaran katalog inilah salah satunya yang memberikan pengaruh terhadap hasil belajar mahasiswa secara menyeluruh. Peningkatan terjadi pada mahasiswa yang melakukan kegiatan pembelajaran dengan menggunakan media pembelajaran katalog, meskipun terdapat 4 mahasiswa yang masih mendapatkan nilai lebih kecil dari nilai posttest. Peneliti melakukan melakukan pencarian informasi kembali kepada keempat mahasiswa ini dan didapati dua mahasiswa mengakui kehabisan waktu untuk 
menjawab pertanyaan, satu mahasiswa sedang dalam kondisi tidak sehat pada saat melakukan posttest dan satu orang mahasiswa menyatakan tidak fokus saat menjawab pertanyaan posttest. Faktor-faktor ini diluar dari kontrol peneliti terhadap sampel pada proses penelitian.

Secara keseluruhan jika disingkronkan antara hasil belajar dengan proses belajar, unsur keaktifan yang terjadi dalam proses pemberian perlakuan mempengaruhi kemampuan mahasiswa dalam mengerti apa yang disampaikan. Penilaian keaktifan dari memperhatikan penjelasan kemudian menyamakan dengan apa yang ada dikatalog, mengikuti instruksi tugas yang ada, mengungkapkan dan menyangga atau menolak pendapat dengan melalui media ini telah memberikan pengalaman belajar yang mempermudah mahasiswa dalam menyerap materi yang dipelajari dan dapat membuat mahasiswa mampu melewati serangkaian tes yang menentukan nilai akhir pembelajaran atau hasil belajar yang lebih baik. Hasil yang baik inilah yang diharapkan dalam suatu akhir pembelajaran. Maka, dapat disimpulkan penggunaan media pembelajaran katalog ini mampu membangun keaktifan sekaligus meningkatkan nilai hasil belajar bagi mahasiswa khususnya dalam materi matematika ekonomi di Universitas PGRI Palembang.

\section{KESIMPULAN}

Berdasarkan hasil pembahasan, peneliti mengambil simpulan sebagai berikut :

1. Pengaruh yang signifikan penggunaan media pembelajaran katalog terhadap keaktifan mahasiswa pada mata kuliah matematika ekonomi Program Studi Pendidikan Akuntansi FKIP Universitas PGRI Palembang. Berdasarkan hasil perhitungan uji ini terjawab pada hasil dari analisis nilai yang didapat pada tes keaktifan (pretest dan posttest) dan dianalisis menggunakan paired sample $t$ test 


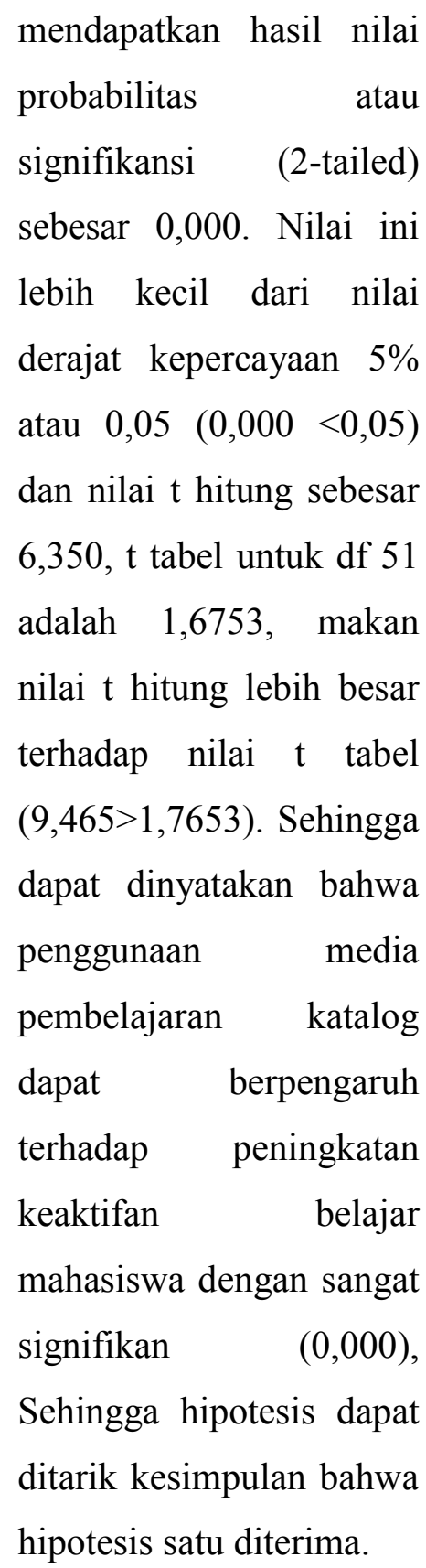

2. Pengaruh yang signifikan

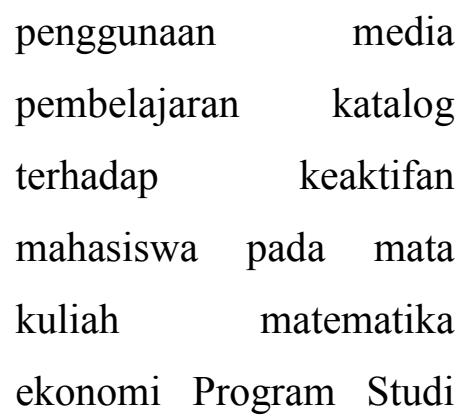

Pendidikan Akuntansi FKIP Universitas PGRI Palembang. Berdasarkan hasil perhitungan uji ini terjawab dengan menggunakan

perhitungan yang sama yaitu paired sample $t$ test dengan menganalisis nilai hasil pretest dan posttest didapatkan hasil nilai probabilitas atau signifikansi (2-tailed) sebesar 0,000. Nilai ini lebih kecil dari nilai derajat kepercayaan $5 \%$ atau $0,05 \quad(0,000<0,05)$ dan nilai $t$ hitung sebesar 9,465, t tabel untuk df 51 adalah 1,6753, makan nilai $t$ hitung lebih besar terhadap nilai $t$ tabel $(9,465>1,6753)$. Sehingga dapat dinyatakan bahwa penggunaan media pembelajaran katalog dapat berpengaruh terhadap peningkatan hasil belajar mahasiswa dengan signifikan $(0,000), \quad$ sehingga 
disimpulkan hipotesis dua diterima.

3. Hasil dari keaktifan belajar mahasiswa kelas 3A $57,89 \%$ dan rata-rata keaktifan belajar mahasiswa kelas 3B $75,45 \%$. Keduanya berada pada kriteria "Aktif", tetapi Keaktifan belajar mahasiswa kelas 3B lebih tinggi dibanding kelas 3A.

4. Rata-rata hasil belajar mahasiswa kelas 3A, yaitu 62,66 dan rata-rata hasil belajar mahasiswa kelas 3B 80,79. Keduanya berada pada kiteria "Baik", tetapi hasil belajar kelas 3B lebih tinggi dibanding kelas $3 \mathrm{~A}$.

\section{DAFTAR PUSTAKA}

\begin{tabular}{lrr} 
Adegbija, M.V dan & M.A. \\
Fakomogbon. & \multicolumn{2}{c}{2012.} \\
Instructional & Media & In \\
Teaching And Learning: A & Learng \\
Nigerian Perspective. & Global \\
Media Journal, vol 6 & $(2)$. \\
(Online) & dari \\
http://dx.doi.org/10.5789/6-2- \\
144, diakses, 10 Oktober 2017.
\end{tabular}

Anitah, Sri. 2009. Media Pembelajaran. Surakarta. LPP UNS dan UNS Press. 2014. Media Pembelajaran. Surakarta. LPP UNS dan UNS Press.

Erowati. T Maria. 2015. Perngaruh Penggunaan Media Benda Konkrit Terhadap Hasil Belajar IPA Siswa Kelas IV $d i \quad S D N$ Sumberejo 01. www.jurnal.fkip.uns.ac.id. ISBN: 978-979-3456-52-2. (Online) dari www.jurnal.fkip.uns.ac.id/ind ex.php/pip/article/view/7735, diakses, 2 Oktober 2017

Hamdani. 2011. Strategi Belajar Mengajar. Bandung : Pustaka Setia.

Sukiyasa K. Sukoco. 2013. Pengaruh Media Animasi Terhadap Hasil Belajar dan Motivasi Belajar Siswa Materi Kelistrikan Otomotif. Jurnal Pendidikan Vokasi, Vol 3. Nomor 1. (Online) dari http://dx.doi.org/10.21831/jp v.v3i1.1588, diakses, 12 Oktober 2017.

Sugiono. 2013. Metode Penelitian Kuantitatif, Kualitatif, dan $R \& D$. Bandung: Alfabeta. $\mathrm{Cv}$.

Suryabrata, S. 2000. Metodologi Penelitian. Jakarta : Raja Grafindo Persada. 